ISSN 1392-3196 / e-ISSN 2335-8947

Zemdirbyste-Agriculture, vol. 108, No. 3 (2021), p. 227-232

DOI 10.13080/z-a.2021.108.029

\title{
Leaching of strontium from Albic Retisol limed with Sr-containing industrial waste
}

\author{
Andrey LITVINOVICH ${ }^{1,2}$, Anton LAVRISHCHEV ${ }^{2}$, Olga PAVLOVA ${ }^{1}$, Vladimir BURE ${ }^{1,3}$, \\ Elmira SALJNIKOV ${ }^{4,5}$
}

\author{
${ }^{1}$ Agrophysical Research Institute \\ Grazhdanskya 14, 195220 St. Petersburg, Russia \\ ${ }^{2}$ St. Petersburg State Agrarian University \\ Peterburgskoye 2, 196601 St. Petersburg, Russia \\ ${ }^{3}$ St. Petersburg State University \\ Universitetskaya 7/9, 199034 St. Petersburg, Russia \\ ${ }^{4}$ Institute of Soil Science \\ Teodora Drajzera 7, 11000 Belgrade, Serbia \\ E-mail: soils.saljnikov@gmail.com \\ ${ }^{5}$ Mitscherlich Academy for Soil Fertility (MITAK) \\ Prof.-Mitscherlich-Allee 1, 14641 Paulinenaue, Germany
}

\begin{abstract}
To study the intensity of migration of stable strontium ( $\mathrm{Sr}$ ) from the light-textured Albic Retisol with different levels of humus content, a column experiment was carried out. As the Sr-containing lime, conversion chalk (CC) as a by-product of nitrogen fertilizer production containing $90 \% \mathrm{CaCO}_{3}$ and $1.5 \% \mathrm{Sr}$ was used. The experiment included 8 washings, where the eluates of each leachate were analysed for the content of Sr leached from the lighttextured Albic Retisol from meadow and forest soils. In a native high-humus soil, complete removal of mobile $\mathrm{Sr}$ was achieved by the $3^{\text {rd }}$ washing; in the low-humus soil, Sr leaching began only after the $3^{\text {rd }}$ washing and did not end after the $8^{\text {th }}$ washing. The total amount of $\mathrm{Sr}$ washed out from the low-humus soil exceeded that of $\mathrm{Sr}$ removed from the soil with a high-humus content by 1.3 times and amounted to 0.21 and $0.16 \mathrm{mg}$, respectively. Liming of the soil with the waste $\mathrm{CC}$ led to its increased leaching of $\mathrm{Sr} 6.1 \mathrm{mg}$ from low-humus soil and $3.8 \mathrm{mg}$ from highhumus soil. The share of CC-Sr leached from limed soils was $24.3 \%$ from high-humus soil and $39.2 \%$ from lowhumus soil of the amount applied with chalk. Empirical equations developed adequately explained the processes of elution of $\mathrm{Sr}$ from native and limed soils. Average rates of the $\mathrm{Sr}$ leaching under the simulated precipitation were: for the native low-humus soil $-0.29 \lg (\mathrm{mg})$ per year, for the calcareous low-humus soil $-0.24 \lg (\mathrm{mg})$ per year and for the calcareous high-humus soil $-0.171 \mathrm{lg}(\mathrm{mg})$ per year.

In the agricultural systems, where systematic and prolonged liming of soils with an ameliorant containing Sr, in order to prevent the ingress of excessive amounts of $\mathrm{Sr}$ into the human body, a systematic monitoring of the content of $\mathrm{Sr}$ in food chains is required.
\end{abstract}

Key words: stable strontium, migration, Albic Retisol, empirical equations, liming.

\section{Introduction}

Strontium ( $\mathrm{Sr}$ ) is an alkaline earth metal that is widespread in nature (Koshy, Pathak, 2020). The average content of stable $\mathrm{Sr}$ in the Earth's crust is $0.04 \%$, and in soils not contaminated with $\mathrm{Sr}$ it ranges from $0.01 \%$ to $0.28 \%$. Naturally occurring Sr is abundant in the Earth's crust - ranking $15^{\text {th }}$ at 340 ppm (Burger, Lichtscheidl, $2019)$ in a form of nonradioactive celestite $\left(\mathrm{SrSO}_{4}\right)$ and strontianite $\left(\mathrm{SrCO}_{3}\right)$ (Sharma, 2020). Strontium occurs naturally in the Earth's mantle as a mixture of four stable isotopes, i.e., $\mathrm{Sr}-84, \mathrm{Sr}-86, \mathrm{Sr}-87$ and $\mathrm{Sr}-88$ (Gupta et al., 2018). The stable and radioactive $\mathrm{Sr}$ isotopes act identically in most physical, chemical and biological processes (Nedobukh, Semenishchev, 2020). In addition, due to similar characteristics of $\mathrm{Sr}$ with calcium $(\mathrm{Ca})$, it enters bodies of organisms via accumulation onto the tissues and bones (Pathak et al., 2020).

In agricultural systems, anthropogenic sources of $\mathrm{Sr}$ are fertilizers and ameliorants made from phosphate raw materials (phosphorites and apatites), where $\mathrm{Sr}$ is in an isomorphic admixture (Лаврищев, Литвинович, 2019). One of such sources of $\mathrm{Sr}$ is a conversion chalk (CC) that is a waste by-product of nitric acid processing

Please use the following format when citing the article:

Litvinovich A., Lavrishchev A., Pavlova O., Bure V., Saljnikov E. 2021. Leaching of strontium from Albic Retisol limed with Srcontaining industrial waste. Zemdirbyste-Agriculture, 108 (3): 227-232. DOI 10.13080/z-a.2021.108.029 
of phosphate raw materials in the production of nitrogen fertilizers. The content of stable $\mathrm{Sr}$ in $\mathrm{CC}$ is about $1.5 \%$. Thomsen and Andreasen (2019) found that the use of agricultural lime was the largest source of anthropogenic Sr in the Karup catchment area, Denmark.

Recently, researchers particularly have focused their interests on $\mathrm{Sr}$ found in soil-groundwater systems (Pathak et al., 2020; Sharma, 2020), since it is highly reactive (Srivastava, Ilyas, 2020), and in aqueous solution it can be bioavailable (Chatterjee et al., 2020; Ilyas et al., 2020).

The available literature data on the migration capacity of $\mathrm{Sr}$ are contradictory. In the studies of Маковский et al. (2008), two years after liming of Albic Retisol with conversion chalk at a dose of $9.9 \mathrm{t} \mathrm{ha}^{-1}$, the presence of $\mathrm{Sr}$ in drainage waters sampled from a depth of $1 \mathrm{~m}$ was not established. On the contrary, irrigation of oasis-gray soil during cotton cultivation led to the movement of Sr to a depth of 110-120 cm (Литвинович, Павлова, 1999). Strontium migrating through soil stratum leaches into groundwater and surface water. Content of carbonates significantly affects the ratio of ${ }^{87} \mathrm{Sr} /{ }^{86} \mathrm{Sr}$ in surface water bodies affected by liming of agricultural soils (Thomsen, Andreasen, 2019).

Currently, the literature recognizes such mechanisms responsible for the movement of $\mathrm{Sr}$ in soil: (1) convective transport with water flow (Cameron, Klute, 1977; Novák, Hlaváčiková, 2019) during infiltration of atmospheric precipitation in the form of soluble salts and complex compounds with organic ligands (Лаврищев, Литвинович, 2019) or mechanically transported solid particles; and (2) due to diffusion in the soil solution (Isermann, 1981; Cole et al., 2000; Kudzin et al., 2020).

The predominant form of vertical migration of $\mathrm{Sr}$ is migration in ionic form (Dubchak, 2018; Sharma, 2020). Earlier studies established that some soil humic substances can fix Srpreventing fromleaching(Лаврищев, Литвинович, 2019), but the different fractions of soil humus can have different effect on releasing and fixing $\mathrm{Sr}$ in soil solution (Burger, Lichtscheidl, 2019). Generally, organic complexation allows $\mathrm{Sr}$ to bind and reduce its mobility. However, the scale of migration of $\mathrm{Sr}$ in soils with a percolation type of water regime of different levels of humus content remains unclear.

Studies on migration capacity of $\mathrm{Sr}$ in Albic Retisol limed with Sr-containing industrial wastes are scarce (Lavrishchev et al., 2021). Empirical equations that adequately describe the processes of leaching of $\mathrm{Sr}$ in native and reclaimed soils have also not been developed. As a working hypothesis of the present experiment, it was suggested that the migratory mobility of stable $\mathrm{Sr}$ in soils of different levels of humus content should differ.

The aim of the research was to conduct a coupled study of the intensity of migration of stable Sr from light textured Albic Retisol with different levels of humus content in the column experiment. The tasks included: (1) to establish the scale of migration of $\mathrm{Sr}$ in native lowhumus and reclaimed soils; (2) to reveal the proportion of soil Sr migrating in reclaimed soil; (3) to develop leaching empirical equations that adequately describe the leaching of Sr during repeated soil wetting, simulating the annual amount of moisture seeping from atmospheric precipitation; (4) to establish the rate of decrease of $\mathrm{Sr}$ content in eluates as the experiment proceeds.

\section{Materials and methods}

Description of studied soils. The column experiment was conducted at the St. Petersburg State Agrarian University, Russia in 2020 on a light-textured Albic Retisol (WRB, 2015). Soil No. 1 was sampled from the native perennial meadow, and soil No. 2 - from native forest.

Table 1 shows basic physicochemical characteristics of the studied soils.

The data from Table 1 indicate that the soils were acidic and had almost the same $\mathrm{pH}_{\mathrm{KC}}$ value and hydrolytic acidity (Hy): 5.4 and $5.6 \mathrm{mmol}^{\mathrm{KCl}}$ (eq) $100 \mathrm{~g}^{-1}$. The total strontium (Sr) content in the soils was close to the background level (156 mg kg $\left.\mathrm{mg}^{-1}\right)$ of Albic Retisol in the North-West of the non-Chernozem zone of Russia (Муравьёв и др., 2015). The soils had a similar content of the particles $<0.001$ and $<0.01 \mathrm{~mm}$ in size.

Table 1. Physicochemical characteristics of the studied Albic Retisol

\begin{tabular}{|c|c|c|c|c|c|c|}
\hline \multirow{2}{*}{$\underset{\%}{\operatorname{Humus}}$} & \multirow{2}{*}{$\mathrm{pH}_{\mathrm{KCl}}$} & $\begin{array}{l}\text { Hydrolytic } \\
\text { acidity }\end{array}$ & $\begin{array}{c}\text { Exchangeable } \\
\text { acidity }\end{array}$ & \multirow{2}{*}{$\begin{array}{c}\mathrm{Sr} \\
\mathrm{mg} \mathrm{kg}^{-1}\end{array}$} & \multicolumn{2}{|c|}{$\begin{array}{c}\text { Soil particles } \\
\% \%\end{array}$} \\
\hline & & \multicolumn{2}{|c|}{ mmol (eq) $100 \mathrm{~g}^{-1}$} & & $<0.001 \mathrm{~mm}$ & $<0.01 \mathrm{~mm}$ \\
\hline \multicolumn{7}{|c|}{ Soil No. 1 (meadow) } \\
\hline $3.02 \pm 0.02$ & $4.1 \pm 0.1$ & $5.4 \pm 0.05$ & $2.5 \pm 0.04$ & $35 \pm 2.10$ & $6.86 \pm 0.04$ & $18.6 \pm 0.60$ \\
\hline \multicolumn{7}{|c|}{ Soil No. 2 (forest) } \\
\hline $1.76 \pm 0.01$ & $4.2 \pm 0.1$ & $5.6 \pm 0.03$ & $0.75 \pm 0.03$ & $12 \pm 1.30$ & $8.98 \pm 0.05$ & $21.6 \pm 0.32$ \\
\hline
\end{tabular}

$\overline{\mathrm{x}} \pm \mathrm{s}$, where $\overline{\mathrm{x}}$ - sample mean, $\mathrm{s}^{2}$ - sample variance, calculated by replicates

The total chemical composition of the soils was determined by the sintering method (Новицкий и др., 2009). The content of soil humus was determined by the Tyurin wet-digestion method (Новицкий и др., 2009). The content of $\mathrm{Sr}$ in the leachates was determined by X-ray fluorescence spectral analyser ORTEC-6111-TEFA (ORTEC Inc., USA). The total content of $\mathrm{Sr}$ was determined on an atomic absorption spectrophotometer (Shimadzu, Japan). The hydrolytic acidity (Hy) was determined according to Kappen (1929): $0.5 \mathrm{M} \mathrm{dm}^{-3} \mathrm{Ca}$-acetate solution adjusted to $\mathrm{pH} 8.2$ was added to the soil in the ratio of 1:2.5. After 1 hour of shaking the suspension was filtrated and followed by titration with $0.1 \mathrm{M} \mathrm{dm}^{-3} \mathrm{NaOH}$ solution. The Hy values were calculated from the amount of alkali consumed $(0.1$ $\mathrm{M} \mathrm{dm}^{-3} \mathrm{NaOH} \mathrm{cm}{ }^{3}$ for $50 \mathrm{~g}$ soil). Exchangeable acidity was determined by the extraction of exchangeable hydrogen and aluminium ions from the soil with a solution of $\mathrm{KCl}$ with a concentration of $1 \mathrm{~mol} \mathrm{dm}^{-3}$ at a soil-to-solution ratio of $1: 2.5$ and subsequent potentiometric titration of the filtrate with sodium hydroxide to pH 8.2 (GOST 2648485. Soils. Method for determining exchangeable acidity). The soil texture was determined by the Kachinsky method (Новицкий и др., 2009); the texture of the conversion chalk was determined by the sieve method.
The total chemical composition of soils is given in Table 2 . The soil from meadow vegetation was characterized by a significantly higher humus content.

Description of liming material conversion chalk (CC). As the Sr-containing material, CC containing 90\% $\mathrm{CaCO}_{3}$ and $1.5 \% \mathrm{Sr}$ was used. It has been used as a liming material for more than 20 years in the Novgorod region, Russia. The reclamation properties of $\mathrm{CC}$ are described in detail by Литвинович et al. (2013) and Лаврищев and Литвинович (2019). The bulk of the chalk is represented by particles with a size of $<0.25 \mathrm{~mm}(99.8 \%)$. This predetermines its high reactivity and rapid dissolution in soils (Table 3).

Experimental design and calculations. The experimental design included two treatments with four replications on the meadow and forest soils with a low- and high-humus content: 1) washing of native soil (control) and 2) washing of limed soil. The height of the soil layer in the funnel was $17 \mathrm{~cm}$, and the weight was 350 $\mathrm{g}$. The density of the filling was $1.0-1.1 \mathrm{~g} \mathrm{~cm}^{-3}$. In total, 8 washings were performed for both soils (Figure 1).

The effect of different levels of humus on the migration ability of $\mathrm{Sr}$ was studied in treatments No. 1 and No. 2 using separating funnels. Before filling the 
Table 2. The total chemical composition (\%) of the studied Albic Retisol

\begin{tabular}{cccccccccc}
\hline $\begin{array}{c}\text { Loss on } \\
\text { ignition }\end{array}$ & $\mathrm{SiO}_{2}$ & $\mathrm{R}_{2} \mathrm{O}_{3}$ & $\mathrm{Fe}_{2} \mathrm{O}_{3}$ & $\mathrm{Al}_{2} \mathrm{O}_{3}$ & $\mathrm{CaO}$ & $\mathrm{MgO}$ & $\mathrm{P}_{2} \mathrm{O}_{5}$ & $\mathrm{SO}_{3}$ & $\mathrm{MnO}$ \\
\hline $6.15 \pm 0.02$ & $81.09 \pm 0.08$ & $9.28 \pm 0.04$ & $1.19 \pm 0.01$ & $7.97 \pm 0.06$ & $0.44 \pm 0.03$ & $0.47 \pm 0.04$ & $0.11 \pm 0.02$ & $0.51 \pm 0.03$ & $1.50 \pm 0.06$ \\
$4.75 \pm 0.01$ & $82.27 \pm 0.06$ & $9.12 \pm 0.05$ & $1.89 \pm 0.02$ & $8.38 \pm 0.05$ & $0.29 \pm 0.02$ & $0.30 \pm 0.03$ & $0.09 \pm 0.01$ & $0.38 \pm 0.02$ & $1.47 \pm 0.08$ \\
\hline$\overline{\mathrm{x}} \pm \mathrm{s}$, where $\overline{\mathrm{x}}$ - sample mean, $\mathrm{s}^{2}-$ sample variance, calculated by replicates & & & & &
\end{tabular}

funnels, the soils were limed with the chalk at a full dose of $1000 \mathrm{mg}$ Hy per column and composted at $28^{\circ} \mathrm{C}$ temperature in a thermostat for 30 days, stirring regularly. Humidity during composting was maintained at $60 \%$ field moisture capacity. After composting, the soils were dried and ground by passing through a sieve with a mesh diameter of $1 \mathrm{~mm}$.

Washing was carried out with a strictly calculated amount of distilled water simulating the volume of moisture seeping through the soil layer annually. The calculations were based on the following data: (1) the annual precipitation in the North-West of the Non-Chernozem zone of Russia ranges from 600 to 650 $\mathrm{mm}$ (https://en.climate-data.org/asia/russian-federation/ saint-petersburg/saint-petersburg-456/); (2) about 400 $\mathrm{mm}$ is spent on transpiration by plants and evaporation from the soil surface (Пестряков, 1977). Thus, $200 \mathrm{~mm}$ of precipitation per year seeps through the soil stratum.

Table 3. Particle size distribution (\%) of conversion chalk

\begin{tabular}{ccccccc}
\hline$>2$ & $2-1$ & $1-0.25$ & $0.25-0.16$ & $0.16-0.09$ & $0.09-0.063$ & $<0.63$ \\
\hline 0 & $0.3 \pm 0.02$ & $0.16 \pm 0.02$ & $4.3 \pm 0.04$ & $24.3 \pm 0.08$ & $41.3 \pm 0.12$ & $21.6 \pm 0.1$ \\
\hline
\end{tabular}

$\overline{\mathrm{x}} \pm \mathrm{s}$, where $\overline{\mathrm{x}}-$ sample mean, $\mathrm{s}^{2}-$ sample variance, calculated by replicates

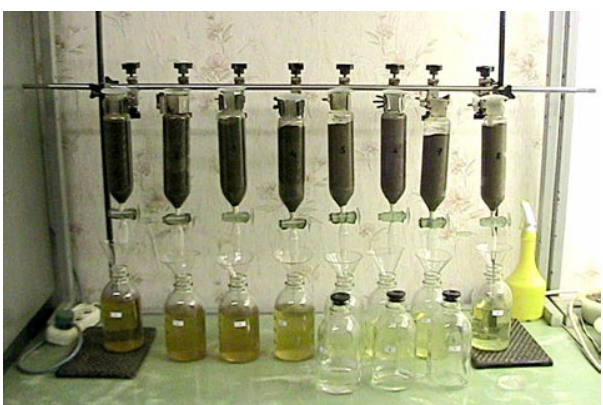

Figure 1. Laboratory experiment to study the migration ability of stable strontium (Sr) in the soil (photo by A. Lavrishchev)

The amount of water required for a single washing of one column was calculated by the formula:

$$
V=\frac{\pi \times r^{2} \times 200}{1000}, \text { where } \pi=3.14 ; r \text { is column }
$$
radius, $\mathrm{mm} ; 1000$ - conversion to millilitre.

According to calculations, $400 \mathrm{ml}$ of distilled water was used for one washing. In total, 8 washings were carried out simulating 8 annual soil wetting with atmospheric moisture. The $\mathrm{Sr}$ content in the leachates was determined using an atomic adsorption spectrophotometer (Shimadzu). Considering the fact that one wash simulates the annual volume of percolating moisture and a year passes between washings in nature, the time is measured in years. Since we logarithm the data using the generalized regression, therefore the unit of measure for rate of leaching $\left(\mathrm{v}_{1}, \mathrm{v}_{2}\right.$ and $\left.\mathrm{v}_{3}\right)$ is $\lg (\mathrm{mg})$ per year. This appproach is often used in data analysis and empirical modeling to avoid negative values in the models. Construction of mathematical equations was carried out according to Бype (2007).

\section{Results and discussion}

The data given in Table 4 show that $\mathrm{Sr}$ was washed out of the soil due to wetting. The maximum content in the eluates removed from the native meadow soil was found in the filtrate of the $1^{\text {st }}$ washing $(0.12 \mathrm{mg})$. In the eluates of the $2^{\text {nd }}$ washing, the amount of migrating Sr decreased three times and amounted to $0.04 \mathrm{mg}$. In the wash water of 3-8 washings, the presence of Sr was not established. This implies that complete removal of the mobile compounds of $\mathrm{Sr}$ was achieved by the $3^{\text {rd }}$ washing. The total amount of leached $\mathrm{Sr}$ from the native meadow soil was $0.16 \mathrm{mg}$. The pool of stable $\mathrm{Sr}$ compounds capable of migrating in high-humus soil was not high and was equal to $0.18 \%$ of its total content. Due to the rapid removal of $\mathrm{Sr}$ from the high-humus soil, an empirical equation could not be created.

A different nature of migration was established in native forest soil with a low-humus content. No Sr was found in the filtrates of the first 3 washings. In the filtrate of the $4^{\text {th }}$ washing, the Sr content was $0.09 \mathrm{mg}$, in the $5^{\text {th }}$ washing it is decreased to $0.04 \mathrm{mg}$ and then it ranged from 0.02 to $0.03 \mathrm{mg}$ until the end of the experiment. Due to the termination of the experiment, it was not possible to establish whether all soil Sr capable of migration in low-humus forest soil was removed after 8 washings. However, in general, the amount of $\mathrm{Sr}$ migrating in native forest soil with a low-humus content was 1.25 times higher than that from high-humus soil.

Since empirical equations cannot take negative values and must correspond to the dynamics of the studied indicator with an increase in the number of washings, the logarithm of the initial data was used to construct

Table 4. The amount (mg) of leached strontium (Sr)

\begin{tabular}{ccccc}
\hline \multirow{2}{*}{ Washing } & \multicolumn{2}{c}{ Soil No. 1 (meadow) } & \multicolumn{2}{c}{ Soil No. 2 (forest) } \\
\cline { 2 - 5 } & native (control) & limed with 1 Hy & native (control) & 0 \\
2 & $0.12 \pm 0.03$ & $1.2 \pm 0.2$ & 0 & 0 \\
2 & $0.04 \pm 0.01$ & $0.4 \pm 0.1$ & $0.09 \pm 0.02$ & $1.5 \pm 0.3$ \\
3 & 0 & $0.5 \pm 0.15$ & $0.04 \pm 0.01$ & $0.8 \pm 0.2$ \\
4 & 0 & $0.4 \pm 0.15$ & $0.02 \pm 0.004$ & $0.8 \pm 0.3$ \\
5 & 0 & $0.4 \pm 0.1$ & $0.02 \pm 0.004$ & $0.3 \pm 0.07$ \\
6 & 0 & $0.3 \pm 0.1$ & $0.03 \pm 0.005$ & $0.3 \pm 0.06$ \\
7 & 0 & $0.2 \pm 0.04$ & 0.2 & $0.3 \pm 0.06$ \\
8 & 0 & 3.8 & 0.18 & 39.3 \\
\hline
\end{tabular}

$\%$ - in native soil from the initial content (control) and in limed soil from the applied with conversion chalk $(\mathrm{CC}) ; \overline{\mathrm{x}} \pm \mathrm{s}, \mathrm{where} \overline{\mathrm{x}}$

- sample mean, $\mathrm{s}^{2}$ - sample variance, calculated by replicates; Hy - hydrolytic acidity 
empirical equations. The paired linear regression after logarithm of the experimental data (starting from the $4^{\text {th }}$ washing, $t=4$ ) of leaching of $\mathrm{Sr}$ from the low-humus forest soil according to the empirical equation:

$\operatorname{In}\left(\mathrm{y}_{1}\right)=-1.66-0.29 \times t$,

where $t$ is conditional time (number of washings) Empirical equation (1) is significant by the $F$-test at a not high level of significance $P$-value $(F)=0.158$ with the coefficient of determination $R^{2}=0.53$.

The average decay rate for the logarithmic data over the entire observation interval: $v_{1}=-0.29 \lg (\mathrm{mg})$. The graph of equation (1), function $y_{1}{ }^{1}(t)=\exp (-1.66-$ $0.29 \times t)$ is shown in the Figure 2 .

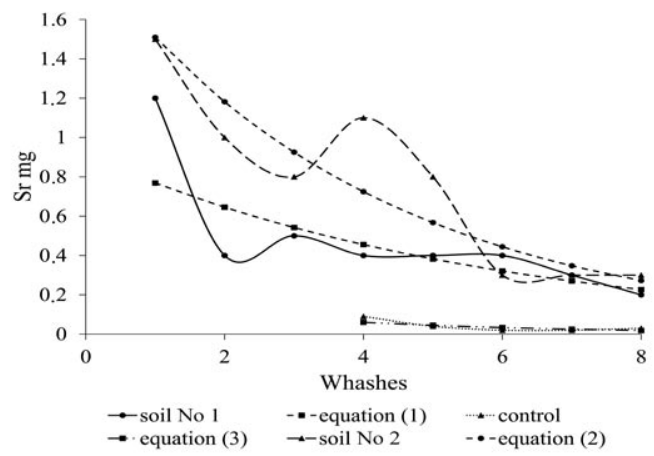

Note. Soil No. 1 - meadow, soil No. 2 - forest; control - the native soil without liming; equation is an empirical description of Sr leaching.

Figure 2. Dynamics of strontium ( $\mathrm{Sr}$ ) content in leachates of the native soil without liming and with a conversion chalk (CC) limed soil

Liming the soils with $\mathrm{CC}$ increases the loss of $\mathrm{Sr}$ by leaching due to washings. The maximum amount of $\mathrm{Sr}$ in the limed meadow soil was also found in the filtrate of the $1^{\text {st }}$ washing. In the eluates of the $2^{\text {nd }}$ washing its content decreased to $0.4 \mathrm{mg}$ (i.e., three times) and then until the end of the experiment ranged from 0.5 to $0.2 \mathrm{mg}$. Consequently, starting from the $2^{\text {nd }}$ washing, the curve of $\mathrm{Sr}$ content in the washing waters was smooth. The total amount of leached Sr over the 8 washings ( 8 experimental years) was $3.8 \mathrm{mg}$. Considering that the amount of soil Sr leached in native and ameliorated soils is a constant value, then the share of leached CC-Sr was $24.3 \%$. Thus, the complete removal of Sr due to washing did not occur. None of the eluates exceeded the maximum permissible concentration of $\mathrm{Sr}$ established for drinking water that is $7 \mathrm{mg} \mathrm{L}^{-1}$ (GOST 2874-82. Drinking water. Hygiene requirements and quality control).

The paired linear regression after logarithm of the experimental data of leaching of Sr from the limed high-humus soil according to the empirical equation:

In $\left(y_{2}\right)=-0.089-0.17 \times t$,

where $t$ is conditional time (number of washings) Empirical equation (2) is significant by the $F$-test at a very high level of significance $P$-value $(F)=0.009$ with the coefficient of determination $R^{2}=0.7$. The average decay rate for the logarithmic data over the entire observation interval: $v^{2}=-0.17 \lg (\mathrm{mg})$. The graph of equation (2), function $y_{2}(t)$ $=\exp (-0.089-0.17 \times t)$ is shown in the Figure 2 .

The maximum amount of $\mathrm{Sr}(1.5 \mathrm{mg})$ leached from the limed soil with a low-humus content occurred in the $1^{\text {st }}$ washing. It by 1.25 times exceeded the amount of Sr leached from the high-humus soil in the $1^{\text {st }}$ washing. Further, throughout the entire period of the experiment, the decrease in the Sr content in the leachates was of a stepwise nature. Thus, the amount of removed $\mathrm{Sr}$ in the filtrates from the $2^{\text {nd }}$ to $4^{\text {th }}$ washings varied from 1.1 to $0.8 \mathrm{mg}$. In the eluates of the $6^{\text {th }}$ to $8^{\text {th }}$ washings, the amount of Sr decreased and was at the level of $0.3 \mathrm{mg}$. A comparative analysis of the data on $\mathrm{Sr}$ content in the eluates of individual washings of the two treatments showed that in all cases the amount of $\mathrm{Sr}$ leached in the treatment with low-humus soil was greater than that from the soil with a high-humus content. The exception was the $7^{\text {th }}$ washing, where the amount of leached $\mathrm{Sr}$ in both treatments was the same.

The total loss of Sr over the entire period of the experiment from the low-humus soil was $6.1 \mathrm{mg} \mathrm{(39.3 \%}$ of the amount applied with chalk minus the share of the soil Sr). This is 1.6 times more than from the soil with a high-humus content. Complete removal of Sr applied with chalk did not occur over the 8 experimental years. None of the eluates was found to exceed the model predictive control (MPC) for Sr for drinking water.

The paired linear regression after logarithm of the experimental data of leaching of Sr from the limed lowhumus meadow soil according to the empirical equation:

In $\left(y_{3}\right)=0.66-0.24 \times t$,

where $t$ is conditional time (number of washings). Empirical equation (3) is significant by the $F$-test at a very high level of significance $P$-value $(F)=$ 0.0017 with the coefficient of determination $R^{2}=0.83$. The average decay rate for the logarithmic data over the entire observation interval: $v_{3}=-0.24 \lg (\mathrm{mg})$. The graph of equation (3), function $y_{3}(t)=\exp (0.66-0.24 \times t)$ is shown in Figure 2.

Empirical equations (2) and (3), built for the logarithmic data, have a very high level of significance according to $F$-test. The average decay rate for the logarithmic data over the entire observation interval for empirical equation (3) is higher than for empirical equation (2). Comparison of the decay rates for empirical equations (2), (3) and (1) is difficult, since the leaching volumes differ greatly and the process of leaching for nonlimed low-humus soil No. 2 (forest) begins only from the $4^{\text {th }}$ washing. The main difference between the treatments of the experiment is that the volumes of leaching for the treatment 2 and 3 (limed soils) are an order of magnitude larger than for the treatment with non-limed soil.

Strontium is an active water migrant (Claval et al., 2002; Dubchak, 2018) and highly reactive alkaline metal (Srivastava, Ilyas, 2020). It migrates especially vigorously in humid landscapes with $\mathrm{Sr}$ ahead of $\mathrm{Ca}$ in terms of the intensity of runoff into the ocean. On the contrary, in our earlier studies carried out in column experiment (Litvinovitch et al., 2015), the intensity of $\mathrm{Ca}$ migration exceeded the mobility of Sr. Humates and fulvates contribute to the fixation of $\mathrm{Sr}$ in soils. In the study of Лаврищев and Литвинович (2019), up to $50 \%$ of the total Sr in Albic Retisol was associated with humic acids. Sharma (2020) suggests that $\mathrm{Sr}$ is strongly fixed by organic substances, clay minerals and oxides in soil environment. In addition, low molecular weight organic substances released by the root system promote the binding of $\mathrm{Sr}$ in the composition of organomineral complexes and, as a result, its migration ability decreases (Лаврищев, Литвинович, 2019). So, organic complexation significantly reduces the mobility of $\mathrm{Sr}$ in soils. However, the binding of $\mathrm{Sr}$ in the organomineral complexes cannot prevent its losses from the soil due to vertical migration, since soil $\mathrm{Sr}$ can migrate as a part of organomineral complexes. Similarly, Dubchak (2018) also found that in the soil poor in humus and nutrients the mobility of $\mathrm{Sr}$ increased significantly, which in turn increased migration rate of ${ }^{90} \mathrm{Sr}$ in plants.

In a column experiment carried out on Albic Retisol light loamy soil limed with dolomite particles of various sizes containing $160 \mathrm{mg} \mathrm{kg}^{-1} \mathrm{Sr}$, the composition of organomineral complexes precipitated was studied (Pavlova et al., 2018). It was found that the content of $\mathrm{Sr}$ in the organomineral complexes varied from 0.67 to 3.1 $\mathrm{g} \mathrm{kg}^{-1}$ of sediment. In the experiment with $\mathrm{CC}$ used for reclamation at a dose of $2.5 \mathrm{Hy}, 5$ years after liming the Sr content migrating in the organomineral complexes was also $3.1 \mathrm{~g} \mathrm{~kg}^{-1}$ (Pavlova et al., 2018). In addition, Frei et al. (2020) found that Sr derived from lime products is efficiently retained near the surface in agricultural farmland in Denmark. Nevertheless, it is eventually released into surface waters and thus significantly alters the isotopic signature of the naturally occurring bioavailable Sr. In addition, in our study, $99.8 \%$ of the chalk used was 
composed by particles with a size of $<0.25 \mathrm{~mm}$ (Table 3 ). This predetermines its high reactivity and rapid dissolution, since the finer the lime particle is the greater the reactive surface area of soils (Heinrich et al., 2020).

A number of studies have shown that the factors that most affect the migration ability of $\mathrm{Sr}$ in soil are moisture (Arapis et al., 1997; Dubchak, 2018; Zhang et al., 2019; Cai et al., 2020; Mikhailovskaya, Pozolotina, 2020) due to high mass flow of $\mathrm{Sr}$ in the liquid phase; soil humus content (Guillén, 2018; Burger, Lichtscheidl, 2019 ) due to its ability to fix Sr compounds; soil acidity (Kashparov et al., 2013; Burger, Lichtscheidl, 2019) and content of exchangeable Ca (Labunska et al., 2021). These parameters are important variables influencing migration ability of $\mathrm{Sr}$ in the soil, which can prevent its downward migration. Although soil organic complexes have the ability to retain Sr applied with lime, Oeser and Blanckenburg (2020) found that the loss of Sr from solid organic matter contributes to the establishment of the isotopic ratio of dissolved or bioavailable $\mathrm{Sr}$.

Therefore, organic matter is a significant export route for Sr-reducing elements. In addition, surface soil layer containing higher amount of organic matter are prone to water erosion. This poses a risk of secondary contamination driven by horizontal migration contributing to the spread of $\mathrm{Sr}$ through the agricultural catchment area (Claval et al., 2002).

\section{Conclusion}

1. The rates of leaching of strontium $(\mathrm{Sr})$ from native low-humus soil were $-0.2 \mathrm{mg}$ and from native high-humus soil $-0.16 \mathrm{mg}$ over the entire observation period implying a possibility of migration of certain compounds of stable $\mathrm{Sr}$ from native soil.

2. The total amount of $\mathrm{Sr}$ leached from the soil with a low-humus content was 1.25 times higher than that leached from the soil with a high-humus content.

3 . Liming of soils with conversion chalk $(\mathrm{CC})$ containing $1.5 \% \mathrm{Sr}$ led to an increase in the volume of $\mathrm{Sr}$ leaching from the soil. Eluvial losses from the lowhumus and high-humus soils corresponded to $39.3 \%$ and $24.3 \%$ of the amount applied with CC, respectively.

4. Systematic liming of with CC may lead to the accumulation of $\mathrm{Sr}$ in the soils and, as a result, contamination of crop production. To prevent the ingress of an excess amount of $\mathrm{Sr}$ into the human body with crop products grown on soil limed with $\mathrm{CC}$, systematic monitoring of the content of $\mathrm{Sr}$ in food chains is required.

\section{Acknowledgments}

Preparation of this paper was supported by the Ministry of Education, Science and Technological Development of the Republic of Serbia (contract No. 451-03-09/2021-14/200011).

Received 24122020

Accepted 31052021

\section{References}

Arapis G., Petrayev E., Shagalova E., Zhukova O., Sokolik G., Ivanova T. 1997. Effective migration velocity of $137 \mathrm{Cs}$ and $90 \mathrm{Sr}$ as a function of the type of soils in Belarus. Journal of Fnvirnnmental Radinactivity $34(?) \cdot 171-185$. https://doi.org/10.1016/0265-93̈1X(9)́́)00013-6

Burger A., Lichtscheidl 1. 2019. Strontium in the environment: review about reactions of plants towards stable and radioactive strontium isntones Science of the Total Fnvirnnment 653: 1458-1512. https://doi.org/10.1016/j.scitotenv.2018.10.312

Cai Y.-H., Yang X. J., Schäter A. I. 2U2U. Kemoval of naturally occurring strontium by nanofiltration/reverse osmosis from oroundwater Memhranes $10(11) \cdot 321$ https://doi.org/10.3390/membranes10110321

Cameron D. R., Klute A. 19\%. Convective-dispersive solute transport with a combined equilibrium and kinetic adsorntion model Water Resources Research 13 (1): 183 188. https://doi.org/10.1029/WR013i001p00183

Chatterjee S., Mitra A., Walther C., Gupta D. K. 2020. Plant response under strontium and phytoremediation. Strontium
Contamination in the Environment. Pathak P., Gupta D. K. (eds). Snringer chanter 5 n. 85-97.

https://doi.org/10.1007/978-3-030-15314-4

Claval D., Real J., Kouxel K. 2002. Mobility and transport of cesiumand strontiumin soilerosionby water. RadioprotectionColloques, 37 (C1): 319-323. https://www.radioprotection. $\mathrm{org} / \mathrm{fr} /$ articles/radinnro/ndf/7007/05/rad $20021 \mathrm{pC} 1-319 . \mathrm{pdf}$ https://doi.org/10.1051/radiopro/2002059

Cole 1., Bidogiio G., Soupioni M., U Gorman M., Gibson N. 2000. Diffusion mechanisms of multiple strontium species in clav Genchimica et Cosmorhimira Acta, $64(3) \cdot 385$ 396. https://doi.org/10.1016/S0016-7037(99)00324-5

Dubchak S. 2U18. Distribution of strontium in soil: interception, weathering, speciation, and translocation to plants. Gupta D., Walther C. (eds). Behaviour of Strontium in Plants and the Envirnnment Snringer n 33-43. https://doi.org/10.1007/978-3-319-66574-0_3

Frei K., Frei K. M., Jessen S. 2U2U. Shallow retardation of the strontium isotope signal of agricultural liming-implications for isoscapes used in provenance studies. Science of the Total Fnvironment 706: 135710 https://doi.org/10.1016/j.scitotenv.2019.13571

Guillen J. 2018. Factors intluencing the soll to plant transfer of strontium. Gupta D., Walther C. (eds). Behaviour of Strontium in Plants and the Environment Snringer, p. 1931. https://doi.org/10.1007/978-3-319-66574-0 2

Gupta D., Deb U., Walther C., Chatterjee S. 2018. Strontium in the ecosystem: transferin plants via root system. Gupta D., Walther C. (eds). Behavior of Strontium in Plants and the Environment. Springer, p. 1-18. https:// www.researchgate.net/publication/328776691_Strontium in the environment Review about reactions of plants towards stahle and radināctive strontium isotopes https://doi-org/10.1007/978-3-319-66574-0 1

Heinrich A., Sulivan D. M., Moore A. D. 2020. Indicators of lime reactivity in soil: particle size carbon dioxide evolution, and critic acid titration Archives of A Aronnmy and Snil Science, 17 p. https://doi.org/10.1080/03650340.2020.1852551

Ilyas S., Srivastava K. R., llyas N. 2020. Biosorption of strontium from aqueous solutions. Pathak P., Gupta D. K. (eds). Strontium Contamination in the Environment. The Handbook of Fnvirnnmental Chemistry Snringer rhanter 4, p. 65-83. https://doi.org/10.1007/978-3-030-15314-4 4

Isermann K. 19rı. Uptake of stabie strontium by plants and effects on plant growth. Skoryna S. C. (ed.). Handbook of Stahle Strontium Snrinoer n 65-86 https://doi.org/10.1007/978-1-4684-3698-3 5

Kappen H. 1Y2Y. Die Bodenaziditat nach agrikulturchemischen Gesichtsnunkten dargestelltt, $363 \mathrm{~S}$. (in German). https://doi.org/10.1002/ange.19290425010

Kashparov V. A., Levchuk S. E., Utreshko L. N., Maloshtan I. M. 2013. Contamination of agricultural production with $90 \mathrm{Sr}$ in Ukraine at the late phase of the Chernobyl accident. Radiation Binlnoy Radinesnlnoy 53 (6). 639-650 (in Russian). https://doi.org/10.786 8 /S0869803113060052

Koshy N., Pathak P. 2U2U. Kemovai of strontium by physicochemical adsorptions and ion exchange methods. Pathak P., Gupta D. K. (eds). Strontium Contamination in the Environment Snringer chanter 10 n. 185-202. https://doi.org/10.1007/978-3-030-15314-4

Kudzin M., Zabrotski V., Garbaruk D., Uhilanets A. 2020. 90Sr in the components of pine forests of Belarusian part of Chernobyl NPP exclusion zone. Pathak P., Gupta D. K. (eds). Strontium Contamination in the Fnvironment Snringer chanter 9, p. 159 183. https://doi.org/10.1007/978-3-030-15314-4 9

Labunska I., Levchuk S., Kashparov V., Holiaka D., Yoschenko L., Santillo D. Johnston P. 2021. Current radiological situation in areas of Ukraine contaminated by the Chernobyl accident. Part 2 . Strontium-90 transfer to culinary grains and forest woods from soils of Ivankiv district. Environmental International, 146: 106282. https://doi.org/10.1016/j.envint.2020.106282

Lavrishchev A. V., Litvinovich A. V., Paviova U. Yu., Bure V. M., Schindler U., Saljnikov E. 2021. Contamination of agroecosystem with stable strontium due to liming: an overview and the experimental data. Salnjikov E. et al. (eds). Advances in Understanding Scil Desradation. Springer. https://doi.org/10.1007/978-3-030-85682-3

Litvinovitch A. V., Lavrishev A. $\bar{V}$, Boore $\bar{V}$. $\mathrm{M}$. Pavlova O. Yu. 2015. The intensity of migration of calcium from soddypodzolic sandy loam soil, liming different doses improver (according to model of experience). Агрохимия, 6: 84-89. (in Russian). https://eposlink.com/catalog/library/elibrary/ book/agrohimiya-2301/publication/128152/

Mikhailovskaya L. N., Pozolotina V. N. 2020. Spatial distribution of $90 \mathrm{Sr}$ from different sources in soils of the 
Ural region, Russia. Pathak P., Gupta D. K. (eds). Strontium Contamination in the Envirnnment Snringer chanter 8 , p. 141-158. https://doi.org/10.1007/978-3-030-15314-4

Nedobukh T. A., Semenishchev V. S. 2020. Strontium: source, occurrence, properties, and detection. Pathak P., Gupta D. K. (eds). Strontium Contamination in the Environment Snringer, chapter 1, p. 1-23. https://doi.org/10.1007/978-3-030-15314-4 1 Novák V., Hlaváčiková H. Züị̄. Transport of solutes in soīis. Applied Soil Hydrology. Theory and Applications of Transport in Pornus Media Snringer vol 32, chanter 14 p. 229-242. https://doi.org/10.1007/978-3-030-01806-1 14

Oeser R. A., Bianckenburg von F. 2U2U. Strontium isotopes trace biological activity in the Critical Zone along a climate and vegetation gradient. Chemical Geology, 558: 119861. https://doi.org/10.1016/j.chemgeo.2020.119861

Pathak P., Srivastava K. K., Keceli (i., Mishra S. 2U2U. Assessment of the alkaline earth metals $(\mathrm{Ca}, \mathrm{Sr}, \mathrm{Ba})$ and their associated health impacts. Pathak P., Gupta D. K. (eds). Strontium Contamination in the Environment Snringer, chanter 12, p. 227-243. https://doi.org/10.1007/978-3-030-15314-4

Pavlova O. Yu., Litvinovich A. V., Lavrischev A. V., Shevchenko E. E., Salaev I. V., BelimovA.A. 2018. Study of leaching soil solutions from reclaimed sod-nodzolic snils. Aгnoхимия 12: 69-76 (in Russian). https://doi.org/10.1134/S0002188118100125

Sharma S. 2020. Uptake, transport, and remediation of strontium. Pathak P., Gupta D. (eds). Strontium Contamination in the Environment. The Handbook of Environmental Chemistry, Snringer chanter 6 n 99-119 https://doi.org/10.1007/978-3-030-15314-4 6

Srivastava K. K., Ilyas S. 2U2U. Strontium extraction from the geo-environment. Pathak P., Gupta D. K. (eds). Strontium Contamination in the Envirnnment Snringer chanter 3, p. 43-63. https://doi.org/10.1007/978-3-030-15314-4 3

Thomsen E., Andreasen K. 2019. Agricultural lime disturbs natural strontium isotopes variations: implications for provenance and migration studies. Science Advances, 5 (3): eaav8083. https://doi.org/10.1126/sciadv.aav8083

WRB. 2015. World reference base for soil resources. World Soil Resources Reports No. 106. FAO, 189 p.

Zhang S., Dai S., Finkelman R. B., Graham I. T., French D. Hower J. C. Li X. 2019. Leaching characteristics of alkaline coal combustion by-products: a case study from a coal-fired nower nlant, Hehei Province, China. Fuel, 255: 115710. https://doi.org/10.1016/j.fuel.2019.115710

Буре В. М. 200\%. Методология статистического анализа опытных данных [Methodology for statistical analysis of experimental data]. Санкт-Петербургский государственный университет, 141 c. (in Russian). https://search.rsl.ru/ru/record/01003385571

Лаврищев А. В., Литвинович А. В. 2019. Стабильный стронций в агроэкосистемах: монография [Stable strontium in agroecosystems: a monograph]. Санкт-Петербург, 192 с. (in Russian). https://e.lanbook.com/book/125719

Литвинович А. В., Лаврищев А. В., Павлова О. Ю., Ковлева А. О. 2013. Последствия применения конверсионного мела для мелиорации кислых почв: стронций в системе дерново-подзолистая почва-растение [Consequences of using conversion chalk for reclamation of acidic soils: strontium in the sod-podzolic soil-plant system]. Почвоведение 9. 1138-1150 (in Russian) httn//elihrary ru/item.asp? https://doi.org/10.7868/S0032180X13090049

Литвинович А. В., ІІавлова U. Ю. 1999. Содержание и особенности распределения валовых и кислоторастворимых форм соединений тяжелых металлов в профиле сероземно-оазисных почв в зоне химического завода [Content and features of distribution of gross and acidsoluble forms of compounds of heavy metals in the profile of gray-oasis soils in the zone of operation of a chemical plant]. Агрохимия, 8: 68-78 (in Russian). https://elibrary.ru/item. asp?id $=19001528$

Маковский Р. Д., Прудников А. Д., Драгунова О. Г. 2008. Миграция стронция, внесенного с мелиорантами [Migration of strontium applied with ameliorants]. Агрохимический вестник, 3: 10-12 (in Russian). https://cyberleninka.ru/article/n/migratsiya-strontsiyavnesennogo-s-meliorantami/viewer

Муравьёв А. Г., Каррыев Б. Б., Ляндзберг А. Р. 2015. Оценка экологического состояния почвы: практическое руководство [Assessment of the ecological state of the soil: practical guide]. Муравьёва А. Г. (ред.). Оценка экологического состояния почвы: практическое руководство. Санкт-Петербург, 208 с. (in Russian). https://www.christmas-plus.ru/images/stories/pdf/ozenkaecologiheskogo-sostoyniy-pochwi.pdf

Новицкий М. В., Донских И. Н., Чернов Д. В., Назарова А. В., Мельников С. П., Баева Н. Н., Лаврищев А. В. 2009. Лабораторно-практические занятия по почвоведению [Laboratory and practical classes in soil science]. СанктПетербург, 321 с. (in Russian). https://elib.pstu.ru/vufind/ Record/RUPSTUbooks153506

Пестряков В. К. 1977. Окультуривание почв Северо-Запада [Cultivation of soils of the North-West]. Ленинград, $345 \mathrm{c}$ (in Russian). http://www.pochva.com/?content=3\&book id $=0780$

\title{
Stroncio (Sr) išplovimas iš dirvožemio, kalkinto stroncio turinčiomis pramonès atliekomis
}

\author{
A. Litvinovičius ${ }^{1,2}$, A. Lavriščevas ${ }^{2}$, O. Pavlova ${ }^{1}$, V. Bure ${ }^{1,3}$, E. Saljnikov ${ }^{4,5}$ \\ ${ }^{1}$ Rusijos agrofizikinių tyrimų institutas \\ ${ }^{2}$ Sankt Peterburgo valstybinis agrarinis universitetas, Rusija \\ ${ }^{3}$ Sankt Peterburgo valstybinis universitetas, Rusija \\ ${ }^{4}$ Serbijos dirvožemio mokslo institutas \\ ${ }^{5}$ Mitscherlich dirvožemio derlingumo akademija (MITAK), Vokietija
}

\section{Santrauka}

Siekiant ištirti stabilaus stroncio ( $\mathrm{Sr}$ ) migracijos intensyvumą iš lengvos granuliometrinès sudèties Albic Retisol dirvožemio su skirtingu kiekiu humuso, buvo atliktas kolonėlių eksperimentas. Kaip Sr šaltinis naudota jo turinti konvertuojamoji kreida, kuri yra azoto trąšų gamybos šalutinis produktas $\left(90 \% \mathrm{CaCO}_{3}\right.$ ir $\left.1,5 \% \mathrm{Sr}\right)$. Eksperimentą sudarė 8 plovimai, kurių metu tirtas Sr kiekis, išplautas iš lengvos granuliometrinès sudėties pievos ir miško Albic Retisol dirvožemio. Visiškas judriojo $\mathrm{Sr}$ pašalinimas iš didelio humusingumo dirvožemio buvo pasiektas per 3-iajji plovimą. Mažai humusingame dirvožemyje Sr išplovimas prasidèjo tik po 3-iojo plovimo ir nesibaige net po 8-ojo. Suminis Sr kiekis, išplautas iš mažai humusingo dirvožemio, 1,3 karto viršijo Sr kiekį, pašalintą iš daug humuso turinčio dirvožemio, ir sudare atitinkamai 0,21 bei $0,16 \mathrm{mg}$. Dirvožemį kalkinant konvertuojamosios kreidos atliekomis, iš mažai humusingo dirvožemio išplauta $6,1 \mathrm{mg}$, iš didelio humusingumo dirvožemio - $3,8 \mathrm{mg}$ daugiau Sr. Iš kalkintu dirvožemių išplauto Sr dalis sudare 24,3 \% (didelio humusingumo dirvožemio) ir 39,2 \% (mažo humusingumo dirvožemio) nuo su kreida įterpto kiekio. Sudarytos empirinès lygtys atskleidè Sr išplovimo iš natūralių ir kalkintų dirvožemių procesą. Esant modeliuojamiems krituliams, $\mathrm{Sr}$ išplovimo vidutinis intensyvumas buvo: iš natūralaus mažai humusingo dirvožemio $-0,29 \lg (\mathrm{mg})$ per metus, iš karbonatingo mažai humusingo dirvožemio $-0,24 \lg (\mathrm{mg})$ per metus, iš karbonatingo didelio humusingumo dirvožemio $-0,17 \lg (\mathrm{mg})$ per metus. Žemès ūkio sistemose, kuriose dirvožemiai ilgą laiką sistemingai kalkinami Sr turinčiais meliorantais (dirvožemio gerinimo medžiagomis), siekiant išvengti per didelio Sr kiekio patekimo i̇ žmogaus organizmą, būtina nuolat stebėti Sr kiekį maisto grandinëje.

Reikšminiai žodžiai: Albic Retisol, empirinès lygtys, kalkinimas, migracija, stabilusis stroncis. 